\title{
Concentration and Risk Evaluation of Polycyclic Aromatic Hydrocarbons in Soils from the Vicinity of Selected Petrol Stations in Kogi State-Nigeria
}

\author{
Julius A. Kadili1,2*, Ishaq S. Eneji ${ }^{2}$, Adams U. Itodo ${ }^{2}$, Rufus Sha'Ato ${ }^{2}$ \\ ${ }^{1}$ Department of Chemistry, Kogi State College of Education (Technical) Kabba, Nigeria \\ ${ }^{2}$ Department of Chemistry and Centre for Agrochemical Technology and Environmental Research, Federal University of \\ Agriculture, Makurdi, Nigeria \\ Email: ^attahjulius85@gmail.com
}

How to cite this paper: Kadili, J.A., Eneji, I.S., Itodo, A.U. and Sha'Ato, R. (2021) Concentration and Risk Evaluation of Polycyclic Aromatic Hydrocarbons in Soils from the Vicinity of Selected Petrol Stations in Kogi State-Nigeria. Open Access Library Journal, 8: e7659.

https://doi.org/10.4236/oalib.1107659

Received: June 18, 2021

Accepted: July 11, 2021

Published: July 14, 2021

Copyright ( $) 2021$ by author(s) and Open Access Library Inc.

This work is licensed under the Creative Commons Attribution International License (CC BY 4.0).

http://creativecommons.org/licenses/by/4.0/

\begin{abstract}
Polycyclic aromatic hydrocarbons (PAHs) are highly teratogenic, persistent, carcinogenic, and ubiquitous environmental contaminants. They present potential threats to the ecological environment and human health. Nine composite soil samples (three from each town) were collected at a depth of $0-30 \mathrm{~cm}$ using soil auger from the vicinity of selected petrol handling facilities (petrol stations) within three major towns in Kogi State-Nigeria, between September and October, 2020. The samples were analyzed for concentrations, distribution, sources and toxic potentials of emission of 16 USEPA priority polycyclic aromatic hydrocarbons (PAHs), since no such comprehensive study had been conducted in the area. The total concentrations of PAHs ( $\Sigma$ PAHs) in soil samples from the vicinity of nine petrol stations within three major towns in Kogi State-Nigeria ranged from 2.66 to $5.64 \mu \mathrm{g} / \mathrm{kg}$ at Ankpa, 1.58 to $7.58 \mu \mathrm{g} /$ $\mathrm{kg}$ at Anyigba and 3.72 to $4.98 \mu \mathrm{g} / \mathrm{kg}$ at Idah, with an average of $4.03 \mu \mathrm{g} / \mathrm{kg}$. Lower molecular weight PAHs (2 - 3 ring PAHs) dominated the PAH profiles, accounting for $69.2 \%$ of total PAH mass. The levels of individual PAHs in all the soil samples were below the Dutch maximum permissible concentration (MPC) for urban residential and agricultural soils. The average benzo[a]pyrene equivalent concentration (BaPeq) of the detected PAHs in the study area was $0.245 \mu \mathrm{g} / \mathrm{kg}$, indicating a relatively low toxicity and carcinogenic potential. Diagnostic ratios of the results showed that PAHs in surface soil samples from the study area were of mixed origin (petrogenic and pyrolytic sources). The Pearson product moment correlation (PPMC) coefficient $(r)$ explored the correlation between the environmental properties and the
\end{abstract}


occurrence of PAHs. Among the physicochemical parameters studied, organic carbon and soil organic matter showed high positive correlation with PAHs concentration. When compared with the Maximum Permissible Concentrations for soil, statistical test at $\mathrm{P}<0.05$ revealed that the difference in PAHs concentrations is not significant. This is an indication that filling station soils in the study area within the period of investigation was safe. However, strict adherence to Department of Petroleum Resources (DPR) guidelines is highly recommended in siting and operating petrol handling facilities to further mitigate the presence of these pollutants.

\section{Subject Areas}

Environmental, Analytical Chemistry

\section{Keywords}

Polycyclic Aromatic Hydrocarbon, Ecological Risk, Health Risk, Petrol Station, Contaminants

\section{Introduction}

An important group of highly ubiquitous environmental pollutants are the Polycyclic Aromatic Hydrocarbons (PAHs). They are released into the environment from both natural (e.g., oil seeps, forest fires and volcanic activity) and anthropogenic sources (e.g., petrochemical industrial effluents, coal tar processing wastes, combustion processes) [1]. They are produced primarily as a result of oil spillage and/or incomplete combustion of organic materials including wood, fossil fuels and petroleum products [2]. Point sources of pollution are usually derived from industrial activities, transport, industrial wastewaters, road runoffs and accidental fuel spills. Thus, due to their frequency and/or associated risk, the U.S. Environmental Protection Agency [3] has selected 16 PAHs as priority pollutants. Their physicochemical properties are shown in Table 1. Due to their low solubility (hydrophobic in nature) and high octanol-water partition coefficient, PAHs may accumulate in the organisms and undergo long-range transport [4] [5] [6]. The occurrence of PAHs in the environment has raised serious concern and has become the subject of many studies. This is because, they are mutagenic and some are carcinogenic [1] [7].

In the terrestrial environment, soil is considered the primary steady sinks for PAHs, because they are readily absorbed by organic matter in soil and difficult to degrade [8] [9] [10]. Furthermore, the accumulation of PAHs in soil may lead to contamination of food chains, which could cause a potential risk to human health [11]. Moreover, the contamination of soil with PAHs may lead to accumulation in vegetables and other biota via food chains, which could cause a potential risk to human health [11] [12]. A possible source of groundwater contamination is leaching of PAHs from contaminated soils [13]. 
Table 1. USEPA's Priority PAHs and their selected properties [18].

\begin{tabular}{|c|c|c|c|c|c|}
\hline PAHs & $\begin{array}{l}\text { Number } \\
\text { of Rings }\end{array}$ & $\begin{array}{c}\text { Molecular } \\
\text { Weight } \\
\left(\mathrm{g} \cdot \mathrm{mole}^{-1}\right)\end{array}$ & $\begin{array}{c}\text { Solubility in } \\
\text { Water } \\
\left(\mathrm{mg} \cdot \mathrm{L}^{-1}\right)\end{array}$ & $\begin{array}{c}\text { Vapor Pressure } \\
\qquad(\mathrm{Pa})\end{array}$ & Log Kow \\
\hline Naphthalene & 2 & 128.17 & 31 & 11.866 & 3.37 \\
\hline Acenaphthene & 3 & 154.21 & 3.8 & 0.500 & 3.92 \\
\hline Acenaphthylene & 3 & 152.2 & 16.1 & 3.866 & 4.00 \\
\hline Anthracene & 3 & 178.23 & 0.045 & $3.40 \times 10^{-3}$ & 4.54 \\
\hline Phenanthrene & 3 & 178.23 & 1.1 & $9.07 \times 10^{-2}$ & 4.57 \\
\hline Fluorene & 3 & 166.22 & 1.9 & 0.432 & 4.18 \\
\hline Fluoranthene & 4 & 202.26 & 0.26 & $1.08 \times 10^{-3}$ & 5.22 \\
\hline Benz[a]anthracene ${ }^{*}$ & 4 & 228.29 & 0.011 & $2.05 \times 10^{-5}$ & 5.91 \\
\hline Chrysene ${ }^{*}$ & 4 & 228.29 & 0.0015 & $1.04 \times 10^{-6}$ & 5.91 \\
\hline Pyrene & 4 & 202.26 & 0.132 & $5.67 \times 10^{-4}$ & 5.18 \\
\hline Benzo[a]pyrene ${ }^{*}$ & 5 & 252.32 & 0.0038 & $6.52 \times 10^{-7}$ & 5.91 \\
\hline Benzo[b]fluoranthene $e^{\star}$ & 5 & 252.32 & 0.0015 & $1.07 \times 10^{-5}$ & 5.80 \\
\hline Benzo[k]fluoranthene ${ }^{\star}$ & 5 & 252.32 & 0.0008 & $1.28 \times 10^{-8}$ & 6.00 \\
\hline Dibenz $[\mathrm{a}, \mathrm{h}]$ anthracene ${ }^{\star}$ & 6 & 278.35 & 0.0005 & $2.80 \times 10^{-9}$ & 6.75 \\
\hline Benzo[g,h,i]perylene & 6 & 276.34 & 0.00026 & $1.33 \times 10^{-8}$ & 6.50 \\
\hline Indeno[1,2,3-cd $]$ pyrene ${ }^{*}$ & 6 & 276.34 & 0.062 & $1.87 \times 10^{-8}$ & 6.50 \\
\hline
\end{tabular}

${ }^{*}$ Carcinogenic PAH.

Several studies ([14] [15] [16] and [17]) have assessed the pollution and health risks of soil PAHs in the vicinity of petrol stations across Nigeria and other parts of the world. However, no data on concentrations of PAHs in petrol stations soils in any part of Kogi State have been reported. Such data are required for understanding the potential risk of PAHs to both humans and animals inhabiting the area. Therefore, the main objectives of this study were: to determine concentrations of PAHs, to assess the potential sources using PAHs diagnostic ratio analysis and to evaluate the possible carcinogenic risk of PAHs in soil samples from the vicinity of petrol handling facilities in Kogi State-Nigeria. This will help in the compilation of baseline data on PAHs in soil samples from the vicinity of petrol stations in the area, thus providing reference data that are essential in monitoring the extent of contamination by toxic substances.

\section{Materials and Methods}

\subsection{Materials}

A global positioning system (GPS), Vortex mixer, Hewlett Packard (HP) 6890 GC/MS, equipped with dual injector, column and other routine laboratory apparatus were employed in this research. Prior to extraction, all glass wares and storage vessels were washed with liquid detergent, soaked in $10 \%$ Nitric acid for 
$48 \mathrm{~h}$ and rinsed with distilled water.

\subsection{Reagents}

Reagents used include analytical grade Acetone, Dichloromethane and standard solutions of the $16 \mathrm{PAHs}$ under investigation (procured from GFS Chemicals, Columbus), silica gel 60 - 200 mesh (Lab tech Chemicals), and anhydrous sodium sulphate (Merck, Germany). These reagents were procured through various sales representatives of the producing companies resident in Nigeria. The reagents were utilized without prior purification, except otherwise stated.

\subsection{Site Description}

Ankpa $\left(7^{\circ} 26^{\prime} \mathrm{N}, 7^{\circ} 38^{\prime} \mathrm{E}\right)$, Anyigba $\left(7^{\circ} 41^{\prime} \mathrm{N}, 7^{\circ} 01^{\prime} \mathrm{E}\right)$ and Idah $\left(7^{\circ} 05^{\prime} \mathrm{N}, 6^{\circ} 45^{\prime} \mathrm{E}\right)$ are major towns in Ankpa, Dekina and Idah Local Government Areas respectively in the Eastern Senatorial Zone of Kogi State, Central Nigeria (Figure 1). The towns cover 1200, 420 and 36 Square Kilometers with estimated population of 267,353; 189,976 and 79815 respectively and temperatures ranging from 28 to $31^{\circ} \mathrm{C}$. The area is the Agricultural and commercial hub of the State, with petrol vending as one of the most lucrative business endeavors. This study's major focus was to assess the quality of soil in the immediate vicinity of petrol handling facilities in the area.

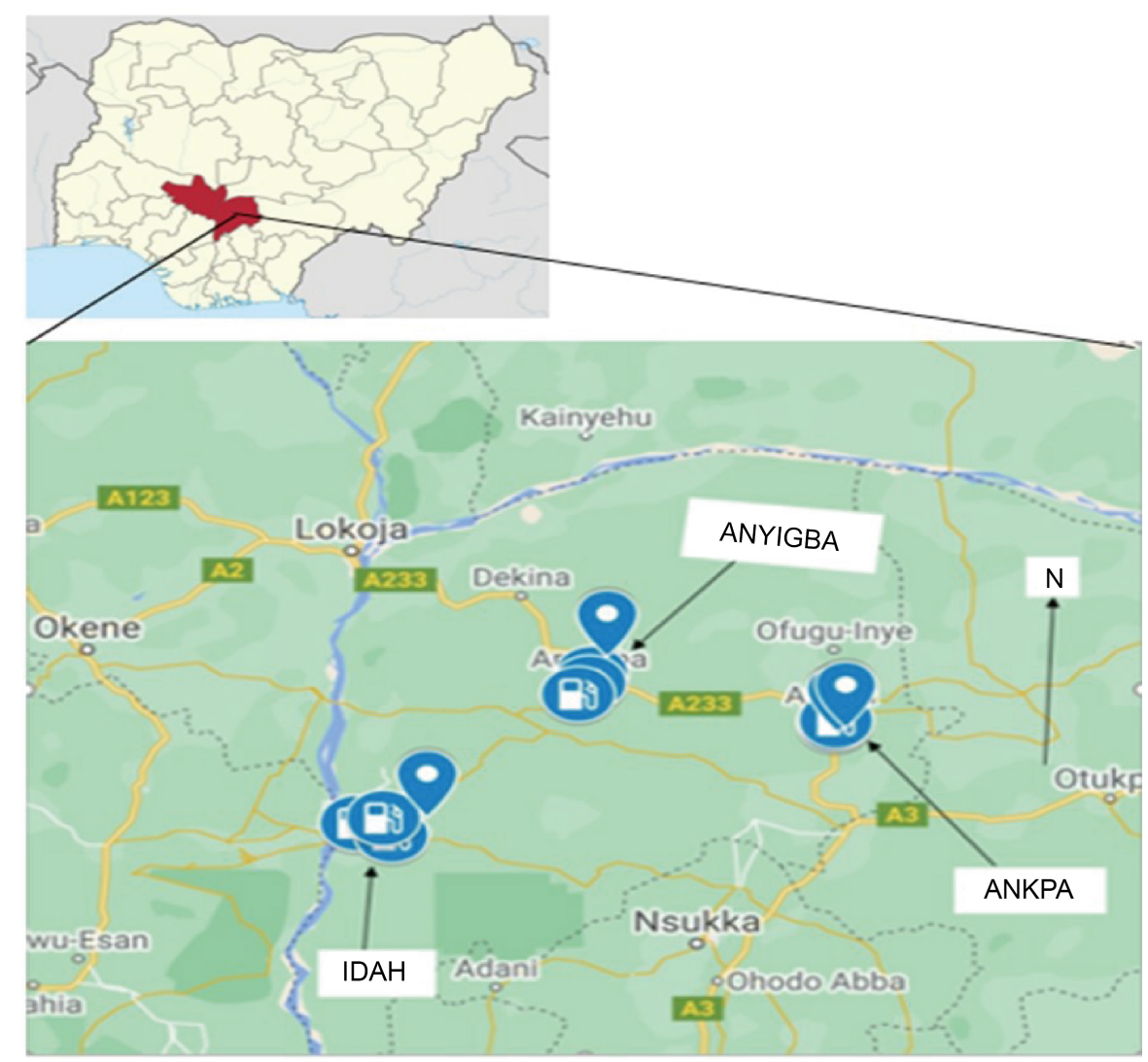

Figure 1. Topographic map of Kogi State showing the soil sample locations. 


\subsection{Sampling}

Three (3) petrol stations each were randomly selected from each town where samples were taken for analysis. A hand soil auger was used to collect soil samples from each station by taking about 6-10 auger borings from five different points to depth of $0-30 \mathrm{~cm}$ ([17] [19] [20] [21] [22]). At each town, a control sample was taken from a pristine site, where petrol station, Agricultural, mining as well as industrial activities were absent, using the same procedure. This was used to determine the background levels of PAHs in areas without pollution sources for comparison. Soil samples at each petrol station were homogenized to give a composite sample. A total of 9 composite soil samples (F1, F2 - F9) and 3 control (C1, C2 and C3) collected from 9 petrol filling stations vicinity in 3 major towns in Kogi East were investigated for toxic petroleum derivatives. Geographical locations of the sampling areas were mapped out by Geographical Positioning System (GPS). The auger was cleaned with water and rinsed with methanol after each sampling point.

Immediately following completion of sampling, all soil samples (wrapped in aluminum foil) were collected in plastic bags and transported to the laboratory, naturally air-dried, homogenized and passed through a $2 \mathrm{~mm}$ sieve to remove non-soil materials such as plant roots and stones, stored in amber glass bottles at $-4^{\circ} \mathrm{C}$ prior to GC-MS pretreatment and analysis [17] [22]. Table 2 shows site description with GPS coordinates.

\subsection{Determination of Physico-chemical Properties of Soil Samples}

Soil Physico-chemical parameters were carried out using standard methods. Soil pH was carried out as adopted by [23] [24]. Particle Size Analysis was done using Hydrometer method as adopted by [25] [26]. Organic Carbon was determined using Wakley-Black acid digestion method as described by [27], Soil organic matter as adopted by [28] and Electrical conductivity was determined as described by [29].

\subsection{PAHs Extraction and Analysis}

Extraction and clean-up of soil samples were carried out according to modified USEPA method (8270) [7] [30]. In summary, the milled sample was properly mixed and $10 \mathrm{~g}$ was weighed into a $50 \mathrm{ml}$ centrifuge tube. Anhydrous sodium sulphate $(1 \mathrm{~g})$ was added and mixed with the sample to absorb any moisture present. The sodium sulphate was previously heated at $650^{\circ} \mathrm{C}$ using oven (Lab. Hot air oven MRC LTD. 3566) for one hour and stored in a desiccator. The main extraction involved the addition of $20 \mathrm{ml}$ of Acetone and Dichloromethane (1:1, $\mathrm{v} / \mathrm{v}$ ). The tube was closed and shaken vigorously by hand for $20 \mathrm{~min}$ using Vortex mixer. To induce phase separation and PAH partitioning, a buffer-salt mixture (consisting of $0.5 \mathrm{~g}$ sodium acetate and $3 \mathrm{~g}$ anhydrous $\mathrm{MgSO}_{4}$ ) was added to the suspension. The tube was closed, shaken vigorously by hand for $1 \mathrm{~min}$, and 
Table 2. Sample code, co-ordinates and description.

\begin{tabular}{|c|c|c|c|c|}
\hline \multirow{2}{*}{$\begin{array}{l}\text { Site/Control } \\
\text { Code }\end{array}$} & \multirow{2}{*}{$\begin{array}{l}\text { Depth } \\
(\mathrm{cm})\end{array}$} & \multicolumn{2}{|c|}{ Co-ordinates } & \multirow{2}{*}{ Site Description } \\
\hline & & Latitude & Longitude & \\
\hline \multicolumn{5}{|l|}{ ANKPA } \\
\hline $\mathrm{F} 1$ & $0-30$ & 7.3799 & 7.6288 & $\begin{array}{l}\text { Vicinity of Petrol station close to residential } \\
\text { area, car wash }\end{array}$ \\
\hline $\mathrm{F} 2$ & $0-30$ & 7.3889 & 7.6307 & $\begin{array}{l}\text { Vicinity of Petrol station, with motor park, op- } \\
\text { posite automobile repair workshop }\end{array}$ \\
\hline F3 & $0-30$ & 7.3558 & 7.6342 & Vicinity of Petrol station, close to a cassava farm \\
\hline $\mathrm{C} 1$ & $0-30$ & 7.3658 & 7.6495 & Pristine site \\
\hline \multicolumn{5}{|l|}{ ANYIGBA } \\
\hline $\mathrm{F} 4$ & $0-30$ & 7.5007 & 7.1788 & $\begin{array}{l}\text { Vicinity of Petrol station, close to residential } \\
\text { area, car wash }\end{array}$ \\
\hline F5 & $0-30$ & 7.4794 & 7.1736 & $\begin{array}{l}\text { Vicinity of petrol station, with motor park, op- } \\
\text { posite an open market. }\end{array}$ \\
\hline F6 & $0-30$ & 7.4519 & 7.1532 & $\begin{array}{l}\text { Vicinity of Petrol station, close to a cassava farm } \\
\text { and an abandoned petrol station. }\end{array}$ \\
\hline $\mathrm{C} 2$ & $0-30$ & 7.5793 & 7.2076 & Pristine site \\
\hline \multicolumn{5}{|l|}{ IDAH } \\
\hline F7 & $0-30$ & 7.1379 & 6.7426 & $\begin{array}{l}\text { Vicinity of Petrol station close to residential } \\
\text { area, car wash }\end{array}$ \\
\hline F8 & $0-30$ & 7.1089 & 6.8069 & Vicinity of Petrol station, close to car wash \\
\hline F9 & $0-30$ & 7.1493 & 6.7928 & $\begin{array}{l}\text { Vicinity of Petrol station, opposite automobile } \\
\text { repair workshop }\end{array}$ \\
\hline $\mathrm{C} 3$ & $0-30$ & 7.1585 & 6.9338 & Pristine site \\
\hline
\end{tabular}

$\mathrm{F}=$ Sampling Station; $\mathrm{C}=$ Control.

centrifuged for $5 \mathrm{~min}$ at $2500 \mathrm{rpm}$. The supernatant was carefully transferred into a flask. The residue was further extracted twice as described above. The solution was then transferred to a sample tube and reduced to about $1 \mathrm{ml}$ under a gentle stream of nitrogen gas using a nitrogen evaporator at $36^{\circ} \mathrm{C}$.

\subsection{Clean-up Procedure}

A column of about $15 \mathrm{~cm}$ (length) $\times 1 \mathrm{~cm}$ (internal diameter) was packed first with glass wool and then with about $10 \mathrm{~g}$ activated silica gel prepared in a slurry form in Dichloromethane. About $10 \mathrm{~g}$ of anhydrous sodium sulphate was placed at the top of the column to absorb any water in the sample or the solvent. Preelution was done with $30 \mathrm{~mL}$ of Dichloromethane, without exposing the sodium sulphate layer to air, so as to prevent the drying up of the silica gel adsorbent. The reduced extract was run through the column and allowed to sink below the sodium sulphate layer. Elution was done with $3 \times 10 \mathrm{~mL}$ portions of the Dichloromethane. The eluate was collected, dried with anhydrous sodium sulphate and evaporated to dryness under a stream of analytical grade nitrogen $(99.99 \%)$ for 
GC-MS analysis.

\subsection{Standard Calibration}

Stock solutions of the sixteen USEPA priority PAHs including naphthalene (NaP), acenaphthene (Ace), acenaphthylene (Acy), fluorine (Flu), phenanthrene (Phe), anthracene (Ant), fluoranthene (Flt), pyrene (Pyr), benzo(a)anthracene (BaA), chrysene $(\mathrm{Chr})$, benzo(b) fluoranthene $(\mathrm{BbF})$, benzo(k) fluoranthene $(\mathrm{BkF})$, benzo(a)pyrene (BaP), indeno(1,2,3-cd)pyrene (InP), dibenzo(a,h) anthracene(DBA), and benzo(g,h,i)perylene (BP) were prepared and then serially diluted to produce different concentrations ranging from 0.5 to $10.0 \mu \mathrm{g} / \mathrm{L}$. Stock standard solutions were stored in amber coloured bottles at $4^{\circ} \mathrm{C}$ in a refrigerator and working standard solutions were prepared fresh before use. Standard solutions of the PAH were run on GC-MS under the set chromatographic conditions and mean peak areas were plotted against concentrations to obtain calibration curves of the PAHs.

\subsection{Quality Assurance/Quality Control}

O-terphenyl was used as a surrogate in checking the recovery of the equipment. $5 \mu \mathrm{l}$ of the $5.0 \mu \mathrm{g} / \mathrm{l}$ of the working standard of the surrogate was spiked to the $1 \mathrm{ml}$ extract containing the PAHs. Control samples collected from pristine sites were also analysed for the PAHs for comparison with the analytical samples. The concentration of the O-terphenyl recovered was used to calculate the percentage recovery of the equipment as shown in Equation (1) [31]

$$
\% \text { Recovery }=(\text { Measured Conc. } / \text { Initial Conc. }) \times 100
$$

The average recoveries of the spiked samples ranged from $94 \%$ to $101.6 \%$.

\subsection{GC-MS Analysis}

After extraction and clean-up, the levels of 16 USEPA priority polycyclic PAHs (naphthalene, acenaphthylene, acenaphthene, fluorene, phenanthrene, anthracene, fluoranthene, pyrene, benzo(a)anthracene, chrysene, benzo(b)-fluoranthene, benzo(k)fluoranthene, benzo(a)pyrene, indenol(1,2,3cd)pyrene, dibenzo(a,h) anthracene, benzo(ghi)perylene) in the extracts were determined using Gas Chromatography-Mass Spectrometry (GC-MS) on a Hewlett Packard (HP) 6890 chromatograph equipped with dual injector and column, under the following conditions (Table 3).

\subsection{Statistical Analysis}

Pearson Correlation coefficient ( $r$ ) was used to compare the mean concentrations of PAHs in soil samples to the soil physico-chemical parameters at $\alpha=0.05$ level of significance. The detected PAHs and their maximum permissible concentrations in soil were also subjected to One-way analysis of variance (ANOVA) using SPSS version 16 adapted for windows. 
Table 3. GC/MS programming conditions.

\begin{tabular}{cc}
\hline Components & Conditions \\
\hline Injector Temperature & $280^{\circ} \mathrm{C}$ \\
Oven Temperature Program & $130^{\circ} \mathrm{C}$ hold for 1 minute $(\mathrm{min}) 5^{\circ} \mathrm{C} / \mathrm{min}$ to $300^{\circ} \mathrm{C}$, \\
& 9 min at $300^{\circ} \mathrm{C}$ \\
Detector Temperature & $320^{\circ} \mathrm{C}$ \\
Carrier Gas & Helium \\
Make-up Gas & Argon $/$ Methane \\
Column Flow Rate & RTX-XLB 2.0 milliliters $/$ minute $(\mathrm{mL} / \mathrm{min}) ;$ \\
Rtx-CLPAH & $1.0 \mathrm{~mL} / \mathrm{min}$ \\
Amount Injected & 1 microliter $(\mu \mathrm{L})$ \\
Data System & HP Chem Station \\
\hline
\end{tabular}

\section{Results and Discussion}

\subsection{Physicochemical Parameters of Soil Samples}

The results of the physico-chemical analysis of the soil samples are given in Table 4 . The result shows that the soil samples are predominantly sandy with low percentages of silt and clay. The $\mathrm{pH}$ of the samples varied between 5.20 and 6.50, showing that the soil samples were slightly acidic compared to the control samples with $\mathrm{pH}$ range between 5.8 and 6.5. Soil $\mathrm{pH}$ is an important index that controls various physicochemical reactions. They exhibit profound degradation effects on PAHs through abiotic and/or biotic routes [7]. According to [32], Soil $\mathrm{pH}$ is the most widely accepted parameter which exerts a controlling influence on the availability of micro-nutrients and heavy metals in the soil to plants. While the anthropogenic activities within and outside petrol stations may have had some direct impact in lowering the $\mathrm{pH}$, it is more likely that production of organic acid by microbial metabolism is responsible for the difference [33]. The normal $\mathrm{pH}$ range for ordinary soils that favor plant and micro-organisms according to [34] is between 5.7 and 6.5. In the current study, three samples (F2, F7 and F8) have pH below 5.7 which clearly shows that the soil samples could probably had undergone some level of pollution. These results are similar to those reported by [26] for soil samples from the vicinity of mechanic workshops in Benin City-Nigeria, but lower than the values $(6.40$ - 7.20) obtained for soil samples collected from the vicinity of selected petrol stations in Benue StateNigeria by [35] and [17], who reported alkaline $\mathrm{pH}$ for petroleum hydrocarbon contaminated soils in the vicinity of petrol station at Hamedan City.

Soil total organic matter determines the fate of PAHs in soil, and microbial degradation of PAHs is restricted to bio-available fractions in soil-pore water and soil particles surface [36]. Organic matter contents in all the samples ranged from $0.69 \%-2.99 \%$. Organic matter content should normally increase following the addition of carbonaceous substances, hydrocarbon fuels or condensates. However, the low levels of OM in the soil samples in the current study could probably 
Table 4. Physicochemical Parameters of Soil Samples from the Vicinity of Petrol Stations.

\begin{tabular}{cccccccc}
\hline Sample Code & $\mathrm{pH}$ & OC $\%$ & SOM $\%$ & $\mathrm{EC}(\mu \mathrm{S} / \mathrm{cm})$ & Sand $\%$ & Silt $\%$ & Clay \% \\
\hline ANKPA & & & & & & & \\
F1 & 6.50 & 0.600 & 1.05 & 21.0 & 81.5 & 13.5 & 5.00 \\
F2 & 5.20 & 1.35 & 2.35 & 13.0 & 68.3 & 20.2 & 11.5 \\
F3 & 6.40 & 0.820 & 1.43 & 22.0 & 79.4 & 10.5 & 10.1 \\
C1 & 5.80 & 0.450 & 0.780 & 28.0 & 80.5 & 12.3 & 7.20 \\
ANYIGBA & & & & & & & \\
F4 & 5.90 & 0.500 & 0.870 & 23.0 & 67.5 & 20.7 & 11.8 \\
F5 & 6.30 & 0.940 & 0.690 & 20.0 & 75.0 & 18.2 & 6.80 \\
F6 & 5.70 & 1.60 & 2.79 & 11.0 & 69.2 & 19.7 & 11.1 \\
C2 & 6.50 & 0.430 & 0.750 & 25.0 & 76.3 & 18.3 & 5.40 \\
IDAH & & & & & & & \\
F7 & 5.50 & 0.980 & 1.71 & 16.0 & 78.6 & 11.8 & 9.60 \\
F8 & 5.30 & 1.20 & 2.09 & 25.0 & 81.2 & 13.2 & 5.60 \\
F9 & 6.00 & 1.72 & 2.99 & 14.0 & 68.9 & 20.9 & 10.2 \\
C3 & 6.60 & 1.49 & 2.59 & 20.0 & 76.3 & 16.3 & 7.40 \\
\hline
\end{tabular}

$\mathrm{OM}=$ organic matter; $\mathrm{SOM}=$ soil organic matter $\mathrm{EC}=$ electric conductivity.

be due to the low levels of PAHs in the area or that a significant quantity of hydrocarbons has not undergone appreciable decomposition or a degradation process. According to [37], two decomposition processes are of significance to the present investigation: the decomposition of the soil organic matter and the decomposition of the added petroleum hydrocarbons. Both decompositions are however, the function of heterotrophic organisms.

Soil conductivity is a measure of the soluble salt content in the soil and is used as an overall indicator of the level of macro- and micro-nutrients in the soil [17] [38]. Electrical conductivity for all the soil samples in the present study ranges from 11.0 to $25.0 \mu \mathrm{S} / \mathrm{cm}$, and increases as the level of PAH decreases. This is in line with [1], who reported same trend for soil samples from around a bitumen field in Nigeria.

Soil texture refers to the relative percentage of sand, silt, and clay within a soil layer. It is a very stable characteristic that influences soil biophysical properties [39]. Results for the particle size analysis of soil samples as shown in Table 4 reveals that the percentage of sand, silt and clay fractions in soil samples range from $67.5-81.5,10.5-20.9$ and $5.00 \%-11.8 \%$ respectively. The soil grain size distribution shows that the study area is predominantly sandy in texture. The percentage clay content in this study is relatively low compared to sand fraction; hence the potential for PAHs adsorption and subsequent immobility. The observed fine particle-size in this study implies that, soil in the study area would aid non-degradation of HPAHs. This is because of its high adsorption ability on 
active fine-soil surfaces. According to [40], fine soil particles less than $0.002 \mathrm{~nm}$ have a larger surface area and hence, a measure of adsorption of contaminants such as PAHs. Reported studies [41] [42] have shown that soil particles with colloidal-size fractions less than $0.002 \mathrm{~nm}$ are major sites of chemical reactions due to the larger specific surface area when compared to sand fractions with larger particle size. However, favorable environmental factors, rate and direction of degradation of PAHs in soil are governed by soil and PAHs characteristics, soil content, run-off, leaching, and sorption and desorption, volatilization and uptake by plants [41]. Results of particle size analysis in this study agrees with those obtained by [35] [26] and [7] for soil samples from petrol stations, auto mechanic workshops and vehicle parks respectively.

\subsection{GC-MS Characterization of Polycyclic Aromatic Hydrocarbons}

Quantitative data revealed the results for the concentrations of individual PAHs detected in the soil extracts as presented in Figure 2 and Table 5. The results also show the mean concentrations and percent abundance of the detected PAHs (Table 6). Toxic equivalent quantities (TEQ), which reveals the extent of ecological and human health risk in the area as well as diagnostic ratio of PAHs revealing the origin of these pollutants are presented in Table 7 and Table 8 respectively.

All the 16 USEPA priority Polycyclic Aromatic Hydrocarbon (except Chry, $\mathrm{BbF}, \mathrm{BkF}$ and $\mathrm{InP}$ ) were detected in the study area. The total concentrations of PAHs ( $\Sigma$ PAHs) in soil samples from the vicinity of nine petrol stations within three major towns in Kogi State-Nigeria ranged from 2.66 to $5.64 \mu \mathrm{g} / \mathrm{kg}$ at Ankpa, 1.58 to $7.58 \mu \mathrm{g} / \mathrm{kg}$ at Anyigba and 3.72 to $4.98 \mu \mathrm{g} / \mathrm{kg}$ at Idah, with the highest concentration $(7.58 \mu \mathrm{g} / \mathrm{kg})$ observed at sample site F6 at Anyigba and lowest value $(1.58 \mu \mathrm{g} / \mathrm{kg})$ at sample site F4 also at Anyigba (Figure 2), with an overall

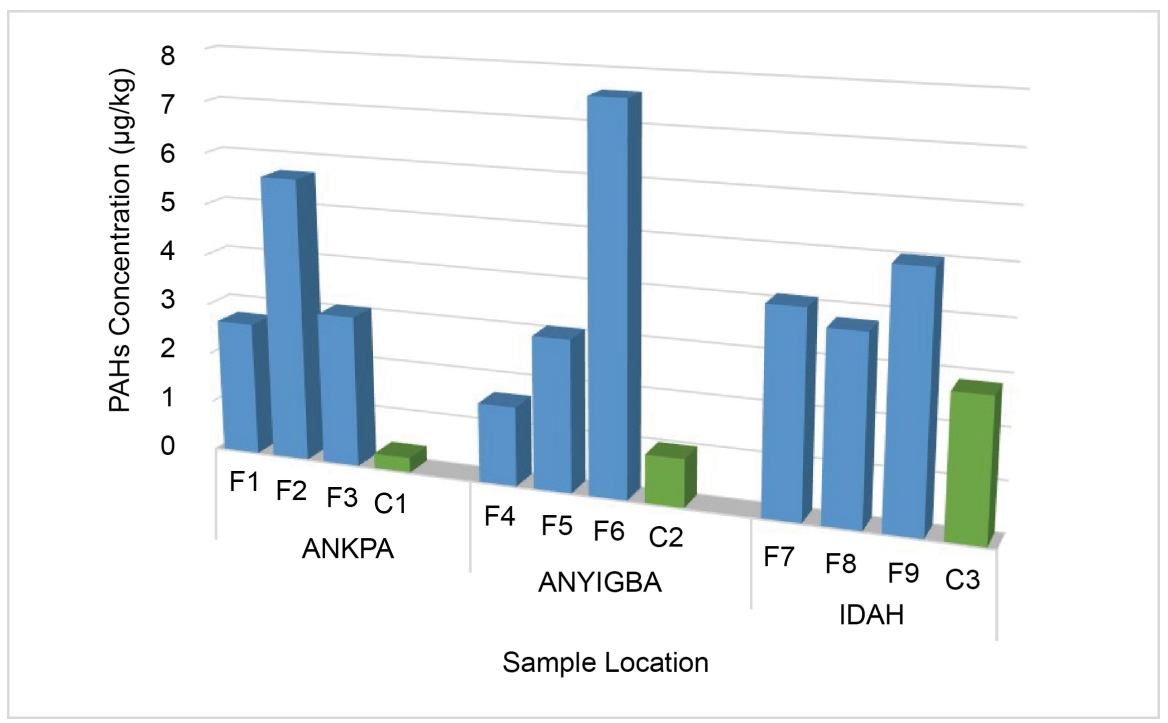

Figure 2. Total PAHs concentration in soil samples and control. 
Table 5. Levels of PAHs $(\mu \mathrm{g} / \mathrm{kg})$ in soil samples from the vicinity of petrol stations.

\begin{tabular}{|c|c|c|c|c|c|c|c|c|c|c|c|c|c|}
\hline \multirow[b]{2}{*}{ PAH } & \multirow[b]{2}{*}{$\mathrm{ABB}$} & \multicolumn{4}{|c|}{$\underline{\text { ANKPA }}$} & \multicolumn{4}{|c|}{ ANYIGBA } & \multicolumn{4}{|c|}{$\underline{\text { IDAH }}$} \\
\hline & & F1 & F2 & F3 & $\mathrm{C} 1$ & F4 & F5 & F6 & $\mathrm{C} 2$ & F7 & F8 & F9 & $\mathrm{C} 3$ \\
\hline Naphthalene & Nap & 0.360 & 1.00 & 0.300 & 0.0800 & 0.180 & 1.06 & 1.00 & 0.540 & 0.940 & 0.820 & 0.480 & 1.00 \\
\hline Acenaphthylene & Acy & 0.340 & 0.180 & 0.260 & 0.180 & 0.120 & 0.280 & 0.200 & 0.420 & 0.320 & 0.000 & 0.160 & 0.100 \\
\hline Acenaphthene & Ace & 0.260 & 1.36 & 0.640 & 0.000 & 0.380 & 0.380 & 1.96 & 0.000 & 0.520 & 0.920 & 1.10 & 0.320 \\
\hline Fluorene & Flu & 0.480 & 0.360 & 0.280 & 0.000 & 0.0800 & 0.220 & 0.560 & 0.000 & 0.220 & 0.300 & 1.44 & 0.460 \\
\hline Anthracene & Ant & 0.140 & 0.780 & 0.500 & 0.000 & 0.180 & 0.360 & 0.180 & 0.000 & 0.360 & 0.360 & 0.960 & 0.360 \\
\hline Phenanthrene & Phe & 0.380 & 0.260 & 0.180 & 0.000 & 0.220 & 0.000 & 0.220 & 0.000 & 0.180 & 0.160 & 0.220 & 0.000 \\
\hline Fluoranthene & Flt & 0.220 & 1.10 & 0.340 & 0.000 & 0.420 & 0.440 & 1.56 & 0.000 & 1.18 & 1.16 & 0.240 & 0.300 \\
\hline Pyrene & Pyr & 0.280 & 0.140 & 0.220 & 0.000 & 0.000 & 0.200 & 0.280 & 0.000 & 0.260 & 0.000 & 0.280 & 0.180 \\
\hline Benz[a]anthracene ${ }^{*}$ & $\mathrm{BaA}$ & 0.000 & 0.260 & 0.300 & 0.000 & 0.000 & 0.000 & 0.000 & 0.000 & 0.000 & 0.000 & 0.000 & 0.000 \\
\hline Chrysene $^{\star}$ & $\mathrm{Chr}$ & 0.000 & 0.000 & 0.000 & 0.000 & 0.000 & 0.000 & 0.000 & 0.000 & 0.000 & 0.000 & 0.000 & 0.000 \\
\hline Benzo[b]fluoranthene ${ }^{*}$ & $\mathrm{BbF}$ & 0.000 & 0.000 & 0.000 & 0.000 & 0.000 & 0.000 & 0.000 & 0.000 & 0.000 & 0.000 & 0.000 & 0.000 \\
\hline Benzo[k]fluoranthene ${ }^{\star}$ & $\mathrm{BkF}$ & 0.000 & 0.000 & 0.000 & 0.000 & 0.000 & 0.000 & 0.000 & 0.000 & 0.000 & 0.000 & 0.000 & 0.000 \\
\hline Benzo[a]pyrene ${ }^{*}$ & $\mathrm{BaP}$ & 0.000 & 0.000 & 0.000 & 0.0400 & 0.000 & 0.000 & 1.62 & 0.000 & 0.000 & 0.000 & 0.000 & 0.000 \\
\hline Dibenzo[a,h]anthracene ${ }^{*}$ & DBA & 0.000 & 0.200 & 0.000 & 0.000 & 0.000 & 0.0800 & 0.000 & 0.000 & 0.0800 & 0.000 & 0.100 & 0.0800 \\
\hline Indenol $[1,2,3$-cd $]$ pyrene ${ }^{*}$ & $\operatorname{InP}$ & 0.000 & 0.000 & 0.000 & 0.000 & 0.000 & 0.000 & 0.000 & 0.000 & 0.000 & 0.000 & 0.000 & 0.000 \\
\hline Benzo[g,h,i]perylene & BP & 0.200 & 0.000 & 0.000 & 0.000 & 0.000 & 0.000 & 0.000 & 0.000 & 0.000 & 0.000 & 0.000 & 0.000 \\
\hline$\Sigma 16 \mathrm{PAH}$ & & 2.66 & 5.64 & 3.02 & 0.300 & 1.58 & 3.02 & 7.58 & 0.960 & 4.06 & 3.72 & 4.98 & 2.80 \\
\hline$\Sigma 7{ }^{*} \mathrm{PAH}$ & & 0.000 & 0.460 & 0.300 & 0.0400 & 0.000 & 0.0800 & 1.62 & 0.000 & 0.0800 & 0.000 & 0.100 & 0.0800 \\
\hline
\end{tabular}

$\mathrm{F}=$ Sampling Site; $\mathrm{C}=$ Control; ${ }^{*}$ Carcinogenic $\mathrm{PAH}$.

Table 6. Mean concentration $(\mu \mathrm{g} / \mathrm{kg})$ and percent abundance of PAHs in the study area.

\begin{tabular}{ccccccc}
\hline PAH & ABBR & $\begin{array}{c}\text { Number of } \\
\text { Rings }\end{array}$ & MEAN & SD & $\begin{array}{c}\text { Abundance } \\
(\%)\end{array}$ & $\begin{array}{c}\text { MPC } \\
(\mu \mathrm{g} / \mathrm{kg})\end{array}$ \\
\hline Naphthalene & Nap & 2 & 0.682 & 0.349 & 16.9 & 690 \\
Acenaphthylene & Acy & 3 & 0.207 & 0.107 & 5.14 & 170 \\
Acenaphthene & Ace & 3 & 0.836 & 0.559 & 20.8 & 680 \\
Fluorene & Flu & 3 & 0.438 & 0.402 & 10.9 & 1,600 \\
Anthracene & Ant & 3 & 0.424 & 0.281 & 10.5 & 340 \\
Phenanthrene & Phe & 3 & 0.202 & 0.100 & 5.01 & 3,600 \\
$\Sigma$ 2-3 Ring PAHs & - & - & 2.79 & 1.79 & 69.2 & - \\
Fluoranthene & Flt & 4 & 0.740 & 0.506 & 18.4 & 4,800 \\
Pyrene & Pyr & 4 & 0.184 & 0.114 & 4.57 & 1,800 \\
Benz[a]anthracene & BaA & 4 & 0.0620 & 0.124 & 1.54 & 190 \\
Chrysene* & Chr & 4 & 0.00 & 0.00 & 0.00 & 1,600 \\
$\sum$ 4 Ring PAHs & - & - & 0.986 & 0.744 & 24.5 & - \\
Benzo[b]fluoranthene & BbF & 5 & 0.00 & 0.00 & 0.00 & 790 \\
Benzo[k]fluoranthene & BkF & 5 & 0.00 & 0.00 & 0.00 & 790 \\
Benzo[a]pyrene & BaP & 5 & 0.180 & 0.540 & 4.47 & 160 \\
Dibenzo[a,h]anthracene & DBA & 6 & 0.0510 & 0.0700 & 1.27 & 180 \\
Indenol[1,2,3-cd]pyrene* & InP & 6 & 0.00 & 0.00 & 0.00 & 380 \\
Benzo[g,h,i]perylene & BP & 6 & 0.0220 & 0.0670 & 0.55 & 490 \\
$\sum$ 5-6 Ring PAHs & - & - & 0.253 & 0.677 & 6.29 & - \\
$\sum 16$ PAHs & - & - & 4.03 & 3.22 & 100 & - \\
\hline
\end{tabular}

$\mathrm{SD}=$ Standard Deviation; $\mathrm{MPC}=$ Maximum Permissible Concentration. 
Table 7. List of TEF and Total Benzo(a)Pyrene-Equivalent Concentration (BaPeq).

\begin{tabular}{ccccc}
\hline PAH & ABBR & TEF & MEAN \pm SD & BaPeq $(\mu \mathrm{g} / \mathrm{kg})$ \\
\hline Naphthalene & Nap & 0.001 & $0.682 \pm 0.349$ & 0.0007 \\
Acenaphthylene & Acy & 0.001 & $0.207 \pm 0.107$ & 0.0002 \\
Acenaphthene & Ace & 0.001 & $0.836 \pm 0.559$ & 0.0008 \\
Fluorene & Flu & 0.001 & $0.438 \pm 0.402$ & 0.0004 \\
Anthracene & Ant & 0.01 & $0.424 \pm 0.281$ & 0.0042 \\
Phenanthrene & Phe & 0.001 & $0.202 \pm 0.100$ & 0.0002 \\
Fluoranthene & Flt & 0.001 & $0.740 \pm 0.506$ & 0.0007 \\
Pyrene & Pyr & 0.001 & $0.184 \pm 0.114$ & 0.0002 \\
Benz[a]anthracene & BaA & 0.1 & $0.0620 \pm 0.124$ & 0.0062 \\
Chrysene & Chr & 0.01 & ND & ND \\
Benzo[b]fluoranthene & BbF & 0.1 & ND & ND \\
Benzo[k]fluoranthene* & BkF & 0.1 & ND & ND \\
Benzo[a]pyrene & BaP & 1 & $0.180 \pm 0.540$ & 0.18 \\
Dibenzo[a,h]anthracene* & DBA & 1 & $0.0510 \pm 0.070$ & 0.051 \\
Indenol[1,2,3-cd]pyrene* & InP & 0.1 & ND & ND \\
Benzo[g,h,i]perylene & BP & 0.01 & $0.0220 \pm 0.067$ & 0.0002 \\
$\sum 16$ PAHs & - & - & $4.03 \pm 3.22$ & 0.245 \\
\hline
\end{tabular}

*Carcinogenic $\mathrm{PAH} ; \mathrm{TEF}=$ toxicity equivalent factor; $\mathrm{SD}=$ standard deviation.

Table 8. Diagnostic Ratio of PAHs Adopted by [7] [53] [54].

\begin{tabular}{cccc}
\hline PAHs Ratio & Value & Origin (source) & Source (Study Area) \\
\hline LMW/HMW & $>1.0$ & Petrogenic & Petrogenic \\
Phen/anthracene & $>15$ & Petrogenic & Pyrolytic \\
Anth/178 & $<0.1$ & Petrogenic & Petrogenic \\
BaA/228 & $<0.2$ & Petrogenic & Petrogenic \\
Chry/BaA & $<0.4$ & Petrogenic & NA \\
Anth/Anth + Phen & $<0.1$ & Petrogenic & Pyrolytic \\
Flt/Flt + Pyr & $<0.4$ & Petrogenic & Pyrolytic \\
Pyr/Flt & $>1$ & Petrogenic & Pyrolytic \\
BaA/BaA + Chry & $<0.2$ & Petrogenic & NA \\
Inp/Inp + BP & $<0.2$ & Petrogenic & NA
\end{tabular}

NA-Not Applicable, since Chry and InP were not detected.

average of $4.03 \mu \mathrm{g} / \mathrm{kg}$. The component of PAHs that is typically of greatest interest in terms of potential cancer hazard is $\mathrm{BaP}$. This compound has been known to exhibit a high carcinogenic activity in animals and has been listed as a proven human carcinogen [43]. BaP was detected in only one sample location (F6) with 
a total concentration of $1.62 \mu \mathrm{g} / \mathrm{kg}$ and in one of the control samples (C1) with a concentration of $0.04 \mu \mathrm{g} / \mathrm{kg}$.

As shown in Figure 3, Figure 4 and Table 6, PAH prevalence as percent abundance at each sample location revealed that higher percentage values obtained are predominantly those for Low Molecular Weight (LMW) PAHs (2 - 3 rings). The ring-wise trend of $\mathrm{PAHs}$ prevalence is clearly revealed at each sample location and in the entire study area. The $\Sigma 2-3$ ring PAHs are the most dominant PAH compounds with concentration of $2.79 \mu \mathrm{g} / \mathrm{kg}$ (69.2\%). Acenaphthylene (5.14\%) and Phenanthrene (5.01\%) are the least in this group. This is followed by the four membered rings ( $\Sigma 4 \mathrm{PAHs}$ ) with concentration of $0.986 \mu \mathrm{g} / \mathrm{kg}$ and percent abundance of $24.5 \%$. The least dominant is the five-six membered rings shown as $\Sigma 5$ - 6 ring PAHs with values as low as $0.253 \mu \mathrm{g} / \mathrm{kg}$ (6.29\%). According to [44], PAHs accumulate in the surface soil by adsorption because of their persistence and affinity for soil organic matter. [45] also noted that the low molecular weight (LMW) PAHs, are easily lost into the atmosphere by volatilization, while some are carried into the soil by water since LMW PAHs have higher water solubility than high molecular weight (HMW) PAHs [46].

The levels of PAHs concentration reported in the current study was generally lower compared to PAHs concentration from similar studies in Nigeria [15] [23] [26] and other parts of the world [47] [17]. This is probably due to major spillage of fuel and other anthropogenic activities as well as more natural presence of hydrocarbon containing materials in those areas.

\subsection{Ecological/Health Risk Assessment}

Pollution levels of PAHs in soil as classified by [48] has 4 categories based on the 16 USEPA priority pollutants, namely, unpolluted $(200 \mu \mathrm{g} / \mathrm{kg})$, weakly polluted

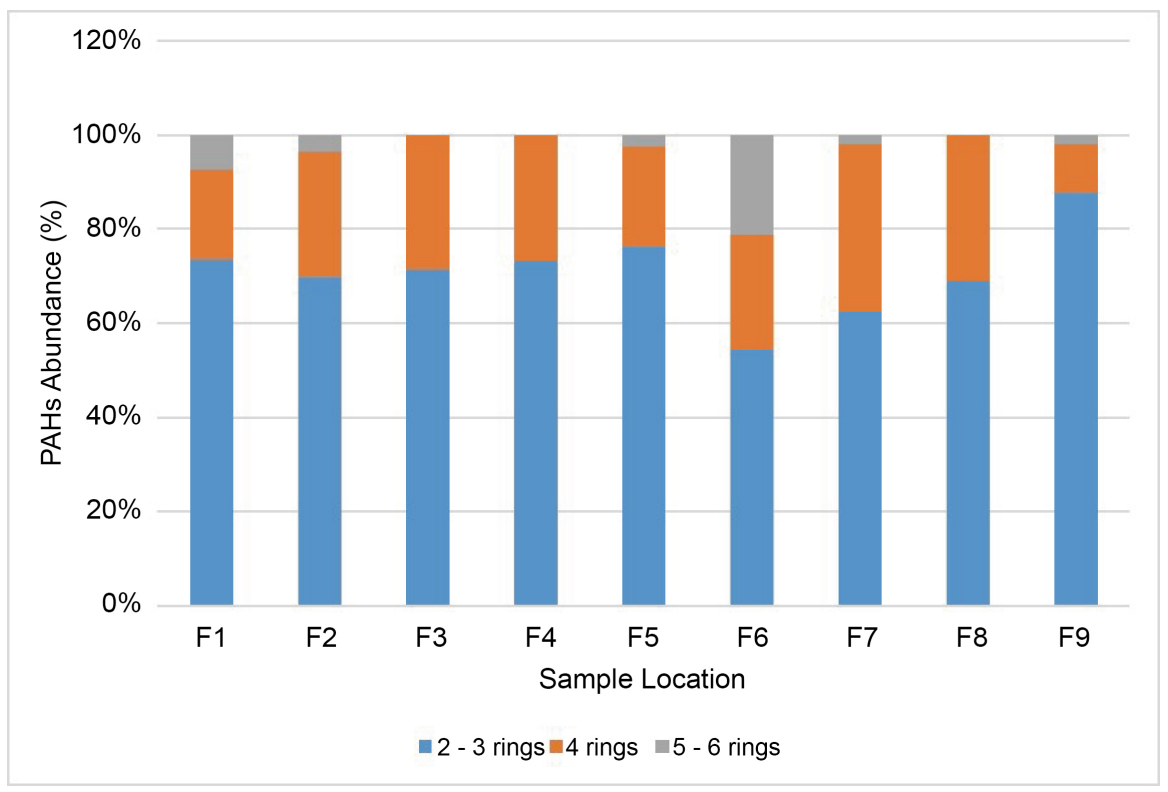

Figure 3. Percent abundance of total PAHs concentration in the samples. 


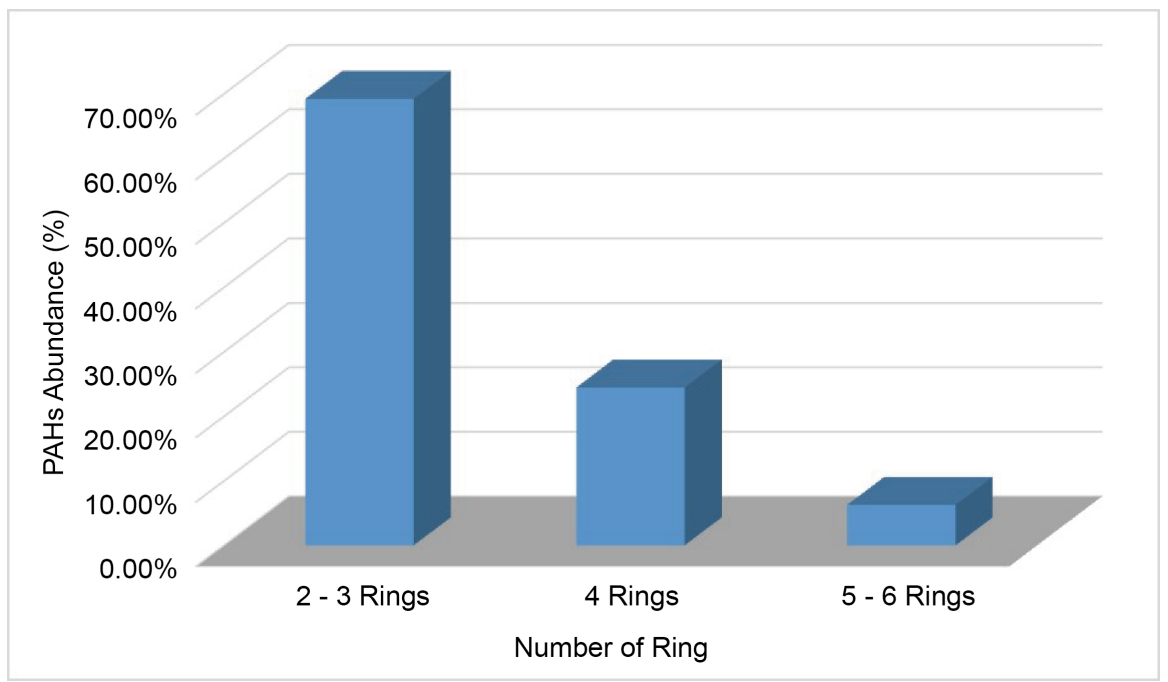

Figure 4. Percent abundance of total PAHs concentration in the study area.

$(200-600 \mu \mathrm{g} / \mathrm{kg})$, polluted $(600-1000 \mu \mathrm{g} / \mathrm{kg})$ and severely polluted (1000 $\mu \mathrm{g} / \mathrm{kg}$ ). By this classification, since the levels of PAHs across all the sites in the area were still under $200 \mu \mathrm{g} / \mathrm{kg}$, it follows therefore, that the area is unpolluted. However, the low over-all concentration of PAHs in the area should not be taken for granted. This is because health risk assessment of carcinogenic PAHs cannot be related only to overall concentration since each PAH has a different carcinogenic potential [49]. Health risk assessment associated with PAHs uptake is often estimated on the basis of the $\mathrm{BaP}$ concentrations. Almost every study refers to $\mathrm{BaP}$ as the highest carcinogenic contributor [50]. The Toxicity equivalency factors (TEFs) as compiled by [51] (Table 7) and adopted by [49] were used to quantify the carcinogenic potential of other PAHs relative to $\mathrm{BaP}$ and to estimate benzo[a]pyrene-equivalent concentration (BaPeq).

The carcinogenic potencies of individual PAHs are determined by multiplying their concentration with the appropriate TEF. The toxicity equivalent concentration (TEQ) is given by Equation (2) [49].

$$
\text { BaPeq }=\sum(C \times T E F)
$$

where $C$ is the determined concentration of individual PAH in soil.

The average benzo[a]pyrene equivalent concentration (BaPeq) of the detected PAHs in the study within the period of investigation was $0.245 \mu \mathrm{g} / \mathrm{kg}$, indicating a relatively low carcinogenic potential, compared to related studies [22] [49] in polluted areas where 1245 and $157.6 \mu \mathrm{g} / \mathrm{kg}$ were reported respectively. Moreover, [52] noted that the Canadian soil environmental quality standard stipulates a safety value for $\Sigma 16 \mathrm{BaPeq}$ in soil of $600 \mu \mathrm{g} / \mathrm{kg}$. It follows therefore, that soils in the vicinity of petrol stations in the study area during the period of this study were safe.

\subsection{Source Identification of PAHs}

According to [55], PAHs are derived from natural or petrogenic sources (in- 
cluding geogenic, forest fires and volcanic activities) and anthropogenic or pyrogenic sources (including oil leakages, oil spills and combustion of fossil fuels). The sources of PAHs in the study area was evaluated by the ratio of detected PAHs mean concentrations and presented in Table 8. In general, as revealed by the diagnostic ratio of PAHs, the ratio LMW/HMW (2.2), Anth/178 (0.002), and $\mathrm{BaA} / 228$ (0.0002) indicates petrogenic source. On the other hand, the ratio Phen/anthracene (0.5), Anth/Anth + Phen (0.67), Pyr/Flt (0.2) reveals pyrolytic sources of the detected PAHs. It follows therefore, that the PAHs detected in the study area were both of petrogenic and pyrolytic origins. Pyrolytic contribution generated mainly through incomplete combustion of organic matter at carbonation temperatures (within 400 degrees) and may probably have resulted from fuel, coal and wood combustion etc. in residential as well as agricultural areas sited close to the petrol stations. The pyrolytic sources are mainly associated with highermolecular-weight PAHs while the petrogenic sources are commonly associated with lower-molecular weight PAHs [56]. However, in the present study, some detected LMWPAHs were found to be of petrogenic origin. This is because, PAHs with 2 - 4 rings are highly volatile and hence are easily transported from one point to another point of impact [54].

\subsection{Correlation Study}

Pearson correlation coefficient (r) PAHs concentrations versus physicochemical parameters was studied and presented in Table 9. According to [47], strength of association expressed by correlation coefficient can be classified according to its value as follows: no association (0 - 0.2); weak (0.2 - 0.4); medium (0.4 - 0.7); strong (0.7 - 0.9); very strong (0.9 - 1.0). From the Pearson correlation coefficients results, both positive and negative correlations were observed. Total PAHs concentrations as shown in Table 9 reveals strong significant positive correlations with total organic carbon (0.872) and soil organic matter (0.848) while $\mathrm{pH}$, electrical conductivity and sand contents show medium $(-0.479)$, high $(-0.807)$

Table 9. Pearson correlation coefficient matrix for TPAHs concentrations versus soil physicochemical parameters.

\begin{tabular}{ccccccccc}
\hline & TPAHs & pH & TOC & SOM & EC & Sand & Silt & Clay \\
\hline TPAHs & 1 & & & & & & \\
pH & -0.479 & 1 & & & & & \\
TOC & 0.872 & -0.456 & 1 & & & & & \\
SOM & 0.848 & -0.529 & 0.927 & 1 & & & \\
EC & -0.857 & 0.307 & -0.726 & -0.688 & 1 & & \\
Sand & -0.396 & 0.265 & -0.412 & -0.375 & 0.579 & 1 & & \\
Silt & 0.338 & -0.189 & 0.413 & 0.305 & -0.485 & -0.925 & 1 & \\
Clay & 0.358 & -0.299 & 0.272 & 0.363 & -0.538 & -0.787 & 0.493 & 1 \\
\hline
\end{tabular}


and medium (-0.395) negative correlations respectively with total PAHs concentrations in the study area. The high positive significant correlation of PAHs with soil organic matter in this study agrees with previous study [57] which reported the same trend in Hong Kong soil. The positive correlation of PAHs with total organic carbon and soil organic matter confirms that samples with high concentrations of organic matter show greater levels of PAHs as shown in Table 9. This also agrees with previous studies [26] which reports that organic matter content should normally increase following the addition of carbonaceous substances, hydrocarbon fuels or condensates. The strong positive correlation may indicate a common source while the negative correlation probably reveals an additional pollution source(s) contributing to the levels of pollutants observed in the study area. However, the major sources of pollutant in the study were mainly anthropogenic.

At $\alpha=0.05$ level (2-tailed) of significance, concentration of PAHs in soil samples shows no significant relationship with their respective control samples. Moreover, one-way ANOVA of PAHs concentrations in soil samples and their respective maximum permissible concentrations (MPC) in soil shows $\mathrm{p}>0.05$, indicating that the PAHs' concentrations detected are not significant and hence, the soil is safe.

\section{Conclusion}

Results of the present study reveal that 14 of the 16 USEPA priority polycyclic Aromatic Hydrocarbons were detected in some soil samples collected from the vicinity of petrol stations in three major towns in Kogi State, Central Nigeria. The detected PAHs were of mixed contributory sources (petrogenic and pyrogenic). Pearson correlation coefficient reveals both positive and negative correlation between PAHs and physicochemical parameters. Difference in concentration of PAHs in soil samples and their control samples are not significant at $\mathrm{p}>$ 0.05 . Similarly, the over-all concentrations of pollutants in the study area were below the maximum permissible limit and therefore, pose no ecological and/or human health risks. However, appropriate measures such as strict adherence to set guidelines and regular monitoring of these pollutants are necessary in ensuring further mitigation of these pollutants in the environment. Moreover, future research perspectives should include the analyses of marketed edibles and plants grown in filling station vicinity for PAHs and other petroleum derivatives to determine any threats to potential consumers.

\section{Conflicts of Interest}

The authors declare no conflicts of interest.

\section{References}

[1] Itodo, A.U., Sha'Ato, R. and Arowojolu, M.I. (2018) Distribution of Polycyclic Aromatic Hydrocarbons (PAHs) in Soil Samples from Regions Around Loda-Irele Bitumen Field, Nigeria. Pakistan Journal of Analytical Environmental Chemistry, 19, 
71-78. https://doi.org/10.21743/pjaec/2018.06.07

[2] Ravindra, K., Sokhi, R. and Grieken, R. (2008) Atmospheric Polycyclic Aromatic Hydrocarbons: Source Attribution, Emission Factors and Regulation. Atmospheric Environment, 42, 2895-2921. https://doi.org/10.1016/j.atmosenv.2007.12.010

[3] USEPA (1993) Provisional Guidance for Quantitative Risk Assessment of PAHs: Environmental Protection Agency. Office of Research and Development, Office of Health and Environmental Assessment, Washington DC, EPA/600/R-93/089.

[4] Peng, C., Chen, W.P., Liao, X.L., Wang, M.E., Ouyang, Z.Y., et al. (2011) Polycyclic Aromatic Hydrocarbons in Urban Soils of Beijing: Status, Sources, Distribution and Potential Risk. Environmental Pollution, 159, 802-808.

https://doi.org/10.1016/j.envpol.2010.11.003

[5] Inomata, Y., Kajino, M., Sato, K., Ohara, T., Kurokawa, J.I., et al. (2012) Emission and Atmospheric Transport of Particulate PAHs in Northeast Asia. Environmental Science and Technology, 46, 4941-4949. https://doi.org/10.1021/es300391w

[6] Zhao, Z.Y., Chu, Y.L. and Gu, J.D. (2012) Distribution and Sources of Polycyclic Aromatic Hydrocarbons in Sediments of the Mai Po Inner Deep Bay Ramsar Site in Hong Kong. Ecotoxicology, 21, 1743-1752.

https://doi.org/10.1007/s10646-012-0948-6

[7] Emoyan, O.O., Onocha, E.O. and Tesi, G.O. (2020) Concentration Assessment and Source Evaluation of 16 Priority Polycyclic Aromatic Hydrocarbons in Soils from Selected Vehicle Parks in Southern Nigeria. Scientific African, 7, 296.

https://doi.org/10.1016/j.sciaf.2020.e00296

[8] Wild, S.R. and Jones, K.C. (1995) Polynuclear Aromatic Hydrocarbons in the United Kingdom Environment: A Preliminary Source Inventory and Budget. Environmental Pollution, 88, 91-108. https://doi.org/10.1016/0269-7491(95)91052-M

[9] Nam, J.J., Song, B.H., Eom, K.C., Lee, S.H. and Smith, A. (2003) Distribution of Polycyclic Aromatic Hydrocarbons in Agricultural Soils in South Korea. Chemosphere, 50, 1281-1289. https://doi.org/10.1016/S0045-6535(02)00764-6

[10] Mueller, K.E. and Shann, J.R. (2006) Polycyclic Aromatic Hydrocarbons in Spiked Soil: Impacts of Bioavailability, Microbial Activity and Trees. Chemosphere, 64, 10061014. https://doi.org/10.1016/j.chemosphere.2005.12.051

[11] Jiang, Y.F., Wang, X.T., Wu, M.H., Sheng, G.Y. and Fu, J.M. (2011) Contamination, Source Identification, and Risk Assessment of Polycyclic Aromatic Hydrocarbons in Agricultural Soil of Shanghai, China. Environmental Monitoring and Assessment, 183, 139-150. https://doi.org/10.1007/s10661-011-1913-1

[12] Li, Y.T., Li, F.B., Chen, J.J., Yang, G.Y., Wan, H.F. and Zhang, T.B. (2008) The Concentrations, Distribution and Sources of PAHs in Agricultural Soils and Vegetables from Shunde, Guangdong, China. Environmental Monitoring and Assessment, 139, 61-76. https://doi.org/10.1007/s10661-007-9816-x

[13] Bispo, A., Jourdain, M.J. and Jauzein, M. (1999) Toxicity and Genotoxicity of Industrial Soils Polluted by Polycyclic Aromatic Hydrocarbons (PAHs). Organic Geochemistry, 30, 947-952. https://doi.org/10.1016/S0146-6380(99)00078-9

[14] Olukoya, E.O., Anna, G.R.E.E. and Oloruntoba, E.O. (2016) Assessment of Soil Contamination with Monocyclic Aromatic Hydrocarbons and Heavy Metals in Residential Areas Sited Close to Fuel Filling Stations in Ibadan Metropolis. Journal of Environment Pollution and Human Health, 4, 60-65.

[15] Ameh, E.G. (2014) A Preliminary Assessment of Soil Samples around a Filling Station in Diobu, Port Harcourt, Rivers State, Nigeria. Research Journal of Environmental and Earth Sciences, 6, 57-65. https://doi.org/10.19026/rjees.6.5742 
[16] Mshelia, A.M., John, A. and Emmanuel, D.D. (2015) Environmental Effects of Petrol Stations at Close Proximity to Residential Buildings in Maiduguri and Jere, Borno State, Nigeria. IOSR Journal of Humanities and Social Sciences, 20, 1-8.

[17] Hassan, P.M., et al. (2015) The Effect of Urban Fuel Stations on Soil Contamination with Petroleum Hydrocarbons. Iranian Journal of Toxicology, 9, 1378-1384.

[18] Bojes, H.K. and Pope, P.G. (2007) Characterization of EPA's 16 Priority Polycyclic Aromatic Hydrocarbons (PAHs) in Tank Bottom Solids and Associated Contaminated Soils at Oil Exploration and Production Sites in Texas. Toxicology and Pharmacology, 47, 288-295. https://doi.org/10.1016/j.yrtph.2006.11.007

[19] Nganje, T.N., Edet, A.E. and Ekwere, S.J. (2007) Distribution of Polycyclic Aromatic Hydrocarbon in Surface Soils from Petroleum Handling Facilities in Calabar Metropolis, Southeastern Nigeria. Environmental Monitoring and Assessment, 130, 27-34. https://doi.org/10.1007/s10661-006-9453-9

[20] Stanković, D., Krstić, B. and Nikolić, N. (2008) Effect of Traffic on the Soil Contamination with Polycyclic Aromatic Hydrocarbons (PAHs). Biotechnology and Biotechnological Equipment, 22, 736-741. https://doi.org/10.1007/s10661-006-9453-9

[21] Eneji, I.S., Vesuwe, R.N. and Sola, O.O. (2017) Analysis of Polyaromatic Hydrocarbons in Soil around Auto-Mechanic Workshops in Major Towns in Benue State, Nigeria. FUW Trends in Science and Technology Journal, 2, 79-84.

[22] Cao, W., Yin, L., Zhang, D., Wang, Y., Yuan, J., Zhu, Y. and Dou, J. (2019) Contamination, Sources, and Health Risks Associated with Soil PAHs in Rebuilt Land from a Coking Plant, Beijing, China. International Journal of Environmental Resources and Public Health, 16, 670-673. https://doi.org/10.3390/ijerph16040670

[23] Ana, G.R.E.E., Mynepalli, K., Sridhar, C. and Emerole, G.O. (2009) A Comparative Assessment of Soil Pollution by Polycyclic Aromatic Hydrocarbons in Two Niger Delta Communities, Nigeria. African Journal of Pure and Applied Chemistry, 3, 3141.

[24] Anegbe, B. and Okuo, J.M. (2013) The Impacts of Quarry Factory on the Physico-Chemical Properties of Soil and Their Potential Health Effects on the Surrounding Ecosystem. Nigeria Journal of Applied Science, 31, 126-135.

[25] Ugbune, U. and Okuo, J. (2011) Sequential Fractionation and Distribution of Heavy Metals in Soil from Battery Work Sites. Nigeria Journal of Applied Science, 29, 132141.

[26] Anegbe, B., Okuo, J.M. and Okieimen, F.E. (2016) The Impact of Inorganic and Organic Pollutants in Soil from the Vicinity of Mechanic Workshops in Benin City. International Journal of Chemical Studies, 4, 106-112.

[27] Emoyan, O.O., Akporido, S. and Agbaire, P.O. (2015) Seasonal Concentration Variation of Polycyclic Aromatic Hydrocarbons (PAHs) of Soils at Sapele Municipality. American Journal of Environmental, Engineering and Science, 2, 9-16.

[28] Ojo, I.O., Ojo, J.O. and Oladele, O. (2015) Analysis of Heavy Metals and Some Physicochemical Parameters in Soil of Major Industrial Dumpsites in Akure Township, Ondo State of South Western Nigeria. International Journal of Chemistry, 7, 225228. https://doi.org/10.5539/ijc.v7n1p55

[29] Olawoyin, R.O. (2012) Application of Expert Systems in the Characterization and Impact of Petroleum Derivatives on Human Health. Unpublished PhD Dissertation, Pennsylvania State University, State College.

[30] Tong, R, Yang, X., Su., H., Pan Y., Zhang, Q., Wang, J. and Long, M. (2018) Levels, Sources and Probabilistic Health Risks of Polycyclic Aromatic Hydrocarbons in the 
Agricultural Soils from Sites Neighboring Suburban Industries in Shanghai. Science of the Total Environment, 616, 1365-1373.

https://doi.org/10.1016/j.scitotenv.2017.10.179

[31] Adekunle, A.S., Oyekunle, J.A.O., Ola, I.J., Obisesan, O.R. and Maxakato, N.W. (2018) Determination of Polycyclic Aromatic Hydrocarbons (PAHs) and Organochlorine Pesticides (OCPs) in Some Personal Care Products in Nigeria. Toxicology Reports, 5, 994-1001. https://doi.org/10.1016/j.toxrep.2018.10.003

[32] Sanders, J.E. (1982) The Effect of $\mathrm{pH}$ upon the $\mathrm{Cu}$ and Cupric Ion Concentrations in Soil Solution. Journal of Soil Science, 33, 679-689. https://doi.org/10.1111/j.1365-2389.1982.tb01799.x

[33] Okoro, D., Oviasogieb, P.O. and Oviasogie, F.E. (2011) Soil Quality Assessment 33 Months after Crude Oil Spillage and Cleanup. Chemical Speciation and Bioavailability, 23, 1-6. https://doi.org/10.3184/095422911X12963991543492

[34] Banjoko, A. and Sobulo, R.A. (1994) Particle Size Distribution of Fe, Mn, Zn, Cu and B in Some Nigerian Soils. Nigeria Journal of Science, 34, 160-163.

[35] Dauda, M.S. and Odoh, R. (2012) Heavy Metals Assessment of Soil in the Vicinity of Fuel Filling Station in Some Selected Local Government Areas of Benue State, Nigeria. Der Chemica Sinica, 3, 1329-1336.

[36] Yang, Y., Tao, S., Zhang, N., Zhang, D.Y. and Li X.Q. (2010) The Effect of Soil Organic Matter on Fate of Transport of Polycyclic Aromatic Hydrocarbons in Soil: A Microcosm Study. Environmental Pollution, 158, 1768-1774. https://doi.org/10.1016/j.envpol.2009.11.010

[37] Osuji, L.C. and Nwoye, I. (2007) An Appraisal of the Impact of Petroleum Hydrocarbons on Soil Fertility: The Owaza Experience. African Journal of Agricultural Research, 2, 318-324.

[38] Ujowundu, C.O., Kalu, F.N., Nwaoguikpe, R.N., Kalu, O.I., Ihejirika, C.E., Nwosunjoku, E.C. and Okechukwu, R.I. (2011) Biochemical and Physical Characterization of Diesel Petroleum Contaminated Soil in Southeastern Nigeria. Research Journal of Chemical Science, 1, 57-62.

[39] Upadhyay, S. and Raghubanshi, A.S. (2020) Determinants of Soil Carbon Dynamics in Urban Ecosystems. In: Urban Ecology, Elsevier, Amsterdam, 299-314. https://doi.org/10.1016/B978-0-12-820730-7.00016-1

[40] Xu, J., Kleja, D.B., Biester, H., Lagerkvist, A. and Kumpiene, J. (2014) Influence of Particle Size Distribution, Organic Carbon, $\mathrm{pH}$ and Chlorides on Washing of Mercury Contaminated Soil. Chemosphere, 109, 99-105. https://doi.org/10.1016/j.chemosphere.2014.02.058

[41] Petruzzelli, G., Gorini, F., Pezzarossa, B. and Pedron, F. (2010) The Fate of Pollutants in Soil. In: Fabrizio, B., Liliana, C. and Pier, F.M., Eds., Environmental Health Inter-Department Project, Consiglio Nazionale delle Ricerche, Roma, 1-31.

[42] Lewis, B.G. (2012) Soil Chemistry. In: Environmental and Ecological Chemistry, Vol. 2, Encyclopedia of Life Support Systems (EOLSS), EOLSS Publishers, Paris, 78115.

[43] World Health Organization WHO (2000) Regional Office for Europe Air Quality Guidelines for Europe. Polycyclic Aromatic Hydrocarbons. European Series, 91. WHO Regional Publications, Copenhagen, 92-96.

[44] Means, J.C., Wood, S.G., Hasset, J.J. and Banwart (1980) Sorption of Polynuclear Aromatic Hydrocarbons by Sediments and Soils. Environmental Science and Technology, 14, 524-528. https://doi.org/10.1021/es60172a005 
[45] Wilson, S.C. and Jones, K.C. (1993) Bioremediation of Soil Contaminated with Polynuclear Aromatic Hydrocarbons (PAHs): A Review. Environmental Pollution, 81, 229-249. https://doi.org/10.1016/0269-7491(93)90206-4

[46] Andersson, B.E., Lundstedt, S., Tornberg, K., Schnürer, Y., Öberg, L.G. and Mattiasson, B. (2003) Incomplete Degradation of Polycyclic Aromatic Hydrocarbons in Soil Inoculated with Wood-Rotting Fungi and Their Effect on the Indigenous Soil Bacteria. Environmental Toxicology and Chemistry, 22, 1238-1243.

https://doi.org/10.1002/etc.5620220608

[47] Rabajczyk, A. and Świercz, A. (2018) Contamination of Soils with Polycyclic Aromatic Hydrocarbons Near Petrol Stations in the City of Kielce. Environment Protection Engineering, 44, 101-115. https://doi.org/10.37190/epe180207

[48] Maliszewska-Kordybach, B. (1996) Polycyclic Aromatic Hydrocarbons in Agricultural Soil in Poland, Preliminary Proposals for Criteria to Evaluate the Level of Soil Contamination. Applied Geochemistry, 11, 121-127. https://doi.org/10.1016/0883-2927(95)00076-3

[49] Bortey-Sam, N., Ikenaka, Y., Nakayama, S., Akoto, O., Yohannes, B.Y., Baidoo, E., Mizukawa, H. and Ishizuka, M. (2014) Occurrence, Distribution, Sources and Toxic Potential of Polycyclic Aromatic Hydrocarbons (PAHs) in Surface Soils from the Kumasi Metropolis, Ghana. Science of the Total Environment, 496, 471-478. https://doi.org/10.1016/j.scitotenv.2014.07.071

[50] Halek, F., Nabi, G. and Kavousi, A. (2008) Polycyclic Aromatic Hydrocarbons Study and Toxic Equivalency Factor (TEFs) in Teheran, Iran. Environmental Monitoring Assessment, 143, 303-311. https://doi.org/10.1007/s10661-007-9983-9

[51] Tsai, P.J., Shih, T.S., Chen, H.L., Lee, W.J., Lai, C.H. and Liou, S.H. (2004) Assessing and Predicting the Exposures of Polycyclic Aromatic Hydrocarbons (PAHs) and their Carcinogenic Potencies from Vehicle Engine Exhausts to Highway Toll Station Workers. Atmospheric Environment, 38, 333-343. https://doi.org/10.1016/j.atmosenv.2003.08.038

[52] Yu, Y, Sun, X., Zou, L., Zhang, H, Liu, Y. and Liu, M. (2020) Polycyclic Aromatic Hydrocarbons (PAHs) in Surface Soil from the Guan River Estuary in China: Contamination, Source Apportionment and Health-Risk Assessment. Science Asia, 46, 80-86. https://doi.org/10.2306/scienceasia1513-1874.2020.013

[53] Adeniji, A.O., Okoh, O.O. and Okoh, A.I. (2018) Analytical Methods for Polycyclic Aromatic Hydrocarbons and Their Global Trend of Distribution in Water and Sediment: A Review. In: Zoveidavianpoor, M., Ed., Recent Insights in Petroleum Science and Engineering, IntechOpen, London. https://doi.org/10.5772/intechopen.71163

[54] Itodo, A.U., Akeju, T.T. and Itodo, H.U. (2019) Polycyclic Aromatic Hydrocarbons (PAHs) in Crude Oil Contaminated Water from Ese-Odo Offshore, Nigeria. Annals of Ecology and Environmental Science, 3, 12-19.

[55] Nganje, T.N., Neji, P.A., Ibe, K.A., Adamu, C.I. and Edet, A. (2014) Fate, Distribution and Sources of Polycyclic Aromatic Hydrocarbons (PAHs) in Contaminated Soils in Parts of Calabar Metropolis, South Eastern Nigeria. Journal of Applied Science and Environmental Management, 18, 309-316.

https://doi.org/10.4314/jasem.v18i2.23

[56] Neff, J.M, Boehm, P.D., Kropp, R., Stubblefield, W.A. and Page, D.S. (2003) Monitoring Recovery of Prince William Sound, Alaska, Following the Exxon Valdez Oil Spill: Bioavailability of PAH in Offshore Sediments. International Oil Spill Conference Proceedings, Vol. 1, 299-305. https://doi.org/10.7901/2169-3358-2003-1-299 
[57] Man, Y.B., Kang, Y., Wang, S.H., Lau, W., Li, H., Sun, X., Giesy, J.P., Chow, K.L. and Wong, H.M. (2013) Cancer Risk Assessments of Hong Kong Soils Contaminated by Polycyclic Aromatic Hydrocarbons. Journal of Hazardous Materials, 261, 770-776. https://doi.org/10.1016/j.jhazmat.2012.11.067 